University of New Hampshire

University of New Hampshire Scholars' Repository

Psychology Scholarship

College of Liberal Arts (COLA)

8-18-2016

\title{
The ability model of emotional intelligence: Principles and updates
}

John D. Mayer

University of New Hampshire, Durham, jack.mayer@unh.edu

David R. Caruso

Yale University

Peter Salovey

Yale University

Follow this and additional works at: https://scholars.unh.edu/psych_facpub

Comments

Mayer, J.D., Caruso, D. R., \& Salovey, P. (2016). The ability model of emotional intelligence: Principles and updates.

Emotion Review, 8, 1-11.. Copyright 2016 (Sage). Reprinted by permission of SAGE Publications. https://dx.doi.org/

$10.1177 / 1754073916639667$

\section{Recommended Citation}

Mayer, J.D., Caruso, D. R., \& Salovey, P. (2016). The ability model of emotional intelligence: Principles and updates. Emotion Review, 8, 1-11. DOI: 10.1177/1754073916639667

This Article is brought to you for free and open access by the College of Liberal Arts (COLA) at University of New Hampshire Scholars' Repository. It has been accepted for inclusion in Psychology Scholarship by an authorized administrator of University of New Hampshire Scholars' Repository. For more information, please contact Scholarly.Communication@unh.edu. 


\title{
The Ability Model of Emotional Intelligence: Principles and Updates
}

\author{
John D. Mayer \\ University of New Hampshire \\ David R. Caruso \\ Yale University \\ Peter Salovey \\ Yale University
}

\begin{abstract}
Author Notes
The authors gratefully acknowledge the assistance of Jessica Hoffmann, Zorana Ivcevic, Kateryna Sylaska, and Ethan Spector, whose comments on an earlier draft strengthened this work in key areas.

Disclosure: The authors receive royalties from MHS of Toronto, Ontario for the MayerSalovey-Caruso Emotional Intelligence Tests (MSCEIT and MSCEIT-YRV).

John D. Mayer, Department of Psychology, University of New Hampshire, Durham, NH 03824; David R. Caruso, Yale College Dean's Office, Yale University, New Haven, CT; Peter Salovey, Department of Psychology, Yale University, New Haven, CT.
\end{abstract}

\begin{abstract}
This article presents several principles that have guided our thinking about emotional intelligence, some of them new. We have reformulated our original ability model here guided by these principles, clarified earlier statements of the model that were unclear, and revised portions of it in response to current research. In this revision, we also positioned emotional intelligence amidst other hot intelligences including personal and social intelligences, and examined the implications of the changes to the model. We discuss the present and future of the concept of emotional intelligence as a mental ability.
\end{abstract}

Keywords: Emotional intelligence, personal intelligence, social intelligence, ability measures, broad intelligences

Prepublication version of:

Mayer, J.D., Caruso, D. R., \& Salovey, P. (2016). The ability model of emotional intelligence: Principles and updates. Emotion Review, 8, 1-11. DOI: 10.1177/1754073916639667 


\section{The Ability Model of Emotional Intelligence: Principles and Updates}

In 1990, two of us proposed the existence of a new intelligence, called "emotional intelligence." Drawing on research findings in the areas of emotion, intelligence, psychotherapy, and cognition, we suggested that some people might be more intelligent about emotions than others (Salovey \& Mayer, 1990, p. 189). We called attention to people's problem solving in areas related to emotion: recognizing emotions in faces, understanding the meanings of emotion words, and managing feelings, among others. We argued that, collectively, such skills implied the existence of a broader, overlooked capacity to reason about emotions: an emotional intelligence (Cacioppo, Semin, \& Berntson, 2004; Haig, 2005). We then characterized the problem-solving people carried out as falling into four areas or "branches" (Mayer \& Salovey, 1997).

In the present article, we revisit the theoretical aspects of our ability model of emotional intelligence, update the model so as to enhance its usefulness, and examine its implications. We begin by considering a set of principles that guide our thinking about emotional intelligence. After discussing these principles, we revise the four-branch model slightly. We then locate emotional intelligence amidst related "broad" intelligences, taking care to distinguish emotional intelligence from personal and social intelligences, and elucidate examples of reasoning for each one of these intelligences. Finally, we wrap up by considering the influence of the model and its implications for the future.

\section{Seven Principles of Emotional Intelligence}

We will describe a set of principles that have guided our theorizing about emotional intelligence. Together, these principles_-guidelines really_-succinctly represent how we think about emotional intelligence.

\section{Principle 1: Emotional Intelligence Is a Mental Ability}

Like most psychologists, we regard intelligence as the capacity to carry out abstract reasoning: to understand meanings, to grasp the similarities and differences between two concepts, to formulate powerful generalizations, and to understand when generalizations may not be appropriate because of context (Carroll, 1993; Gottfredson, 1997). We agree also that intelligence can be regarded as a system of mental abilities (Detterman, 1982).

Regarding how people reason about emotions, we proposed that emotionally intelligent people (a) perceive emotions accurately, (b) use emotions to accurately facilitate thought, (c) understand emotions and emotional meanings and (d) manage emotions in themselves and others (Mayer \& Salovey, 1997).

\section{Principle 2: Emotional Intelligence Is Best Measured As an Ability}

A key component of our thinking is that intelligences are best measured as abilities - by posing problems for people to solve, and examining the resulting patterns of correct answers (Mayer, 2015). (Correct answers are those that authorities identify within the problem-solving area.) The best answers to a question can be recognized by consulting reference works, convening a panel of experts, or (more controversially for certain classes of problems), by identifying a general consensus among the test-takers (Legree, Psotka, Tremble, \& Bourne, 2005; MacCann \& Roberts, 2008; Mayer, Salovey, Caruso, \& Sitarenios, 2003). 
People are poor at estimating their own levels of intelligence-whether it is their general intelligence or their emotional intelligence (Brackett, Rivers, Shiffman, Lerner, \& Salovey, 2006; Paulhus, Lysy, \& Yik, 1998). Because people lack knowledge of what good problem solving actually entails, they estimate their abilities on other bases. These include a non-informative mix of general self-confidence, self-esteem, misunderstandings of what is involved in successful reasoning, and wishful thinking. These non-intellectual features add construct-irrelevant variance to their self-estimated abilities, rendering them invalid as indices of their actual abilities (Joint Committee, 2014).

\section{Principle 3: Intelligent Problem Solving Does Not Correspond Neatly to Intelligent Behavior}

We believe there is a meaningful distinction between intelligence and behavior. A person's behavior is an expression of that individual's personality in a given social context (Mischel, 2009). An individual's personality includes motives and emotions, social styles, selfawareness, and self-control, all of which contribute to consistencies in behavior, apart from intelligence. Among the Big Five personality traits, for example, extraversion, agreeableness and conscientiousness correlate near zero with general intelligence. Neuroticism correlates at $r=-$ .15 , and openness about $r=.30$ (DeYoung, 2011). The Big Five exhibit correlations of similar magnitude with emotional intelligence: Neuroticism correlates $r=-.17$ with emotional intelligence and openness $r=.18$; extraversion and conscientiousness correlate with emotional intelligence between $r=.12$ to .15 , and agreeableness, $r=.25$ (Joseph \& Newman, 2010). These correlations indicate the relative independence of intelligences from socioemotional styles. They confirm what everyday observation suggests: that emotionally stable, outgoing, and conscientious people may be emotionally intelligent or not.

Similarly, a person may possess high analytical intelligence but not deploy itillustrating a gap between ability and achievement (Duckworth, Quinn, \& Tsukayama, 2012; Greven, Harlaar, Kovas, Chamorro-Premuzic, \& Plomin, 2009). Intelligence tests tend to measure potential better than the typical performance of everyday behavior. Many people with high levels of intelligence may not deploy their ability when it would be useful (Ackerman \& Kanfer, 2004). For these reasons, the prediction from intelligence to individual instances of "smart" behavior is fraught with complications and weak in any single instance (Ayduk \& Mischel, 2002; Sternberg, 2004). At the same time, more emotionally intelligent people have outcomes that differ in important ways from those who are less emotionally intelligent. They have better interpersonal relationships both in their everyday lives and on the job-as articles in this issue and elsewhere address (Izard et al., 2001; Karim \& Weisz, 2010; Mayer, Roberts, \& Barsade, 2008; Mayer, Salovey, \& Caruso, 2008; Roberts et al., 2006; Rossen \& Kranzler, 2009; Trentacosta, Izard, Mostow, \& Fine, 2006)

Although intelligences predict some long-term behavioral outcomes, predicting any individual behavior is fraught with uncertainty because of the other personality - and socialvariables involved (Funder, 2001; Mischel, 2009).

\section{Principle 4: A Test's Content - the Problem Solving Area Involved-Must Be Clearly Specified as a Precondition for its Measurement of Human Mental Abilities}

Establishing the Content of the Area. To measure emotional intelligence well, tests must sample from the necessary subject matter; the content of the test must cover the area of problemsolving (Joint Committee, 2014). A test of verbal intelligence ought to sample from a wide range of verbal problems in order to assess a test-taker's problem-solving ability. Test developers therefore must cover the key areas of verbal problem-solving required, such as understanding 
vocabulary, comprehending sentences and other, similar skills. The specification of a problemsolving area-vocabulary, sentence comprehension, and the like for verbal reasoning - defines the intelligence and its range of application. The content specification is designed to ensure that the test samples a representative group of problems.

Subject Matter Differs from Ability. Once the test's content is established, the test can be used to identify a person's mental abilities. People's problem-solving abilities are reflected by the correlational (or covariance) structure of the responses they make to the test items. People's abilities are revealed when a group of scores on test-items rise and fall together across a sample of individuals. Note that the mental abilities measured by a test are independent to some degree from the nature of the problems to be solved. That is, a person's abilities will not necessarily correspond directly to the different types of content in a subject area-a matter we consider further in the next principle.

\section{Principle 5: Valid Tests have Well-Defined Subject Matter that Draws out Relevant Human Mental Abilities}

People exhibit their reasoning abilities as they solve problems within a given subject area. As such, a test's validity depends both on the content it samples and the human mental abilities it elicits. From this perspective, test scores represent an interaction between a person's mental abilities and the to-be solved problems. If the test content is poorly specified, the items will misrepresent the domain, and any hoped-for research understanding of mental abilities may be inconclusive. If problem-solving domains overlap too much with other areas, ability factors redundant with other areas may emerge; if the test content is too broad, eclectic sets of ability factors may arise, and if the content is too narrow the test may fail to draw out key mental abilities. A garbage-in, garbage-out process will replace good measurement.

As implied above, human abilities do not necessarily map directly onto test content: The abilities people use to solve problems have their own existence independent of the organization of the subject matter involved. In the intelligence field, a test of verbal knowledge may ask a person questions about non-fiction passages, fiction, poetry, and instruction manuals. Despite the diversity of material, people use just one verbal intelligence to comprehend them all. On the other hand, the skill to identify what is missing in a picture and the skill to rotate an object in space (in our minds) appear to draw on the same visual understanding. However, identifying the missing part of a picture draws primarily on perceptual-organizational intelligence whereas the object-rotation task draws primarily on spatial ability, and these mental abilities are distinct (Wai, Lubinski, \& Benbow, 2009). As applied to emotional intelligence, we need both to describe accurately the emotional problem solving that people undertake and the abilities people employ to solve those problems - which are two different matters (Joint Committee, 2014).

\section{Principle 6: Emotional Intelligence is a Broad Intelligence.}

We view emotional intelligence as a "broad" intelligence. The concept of broad intelligences emerges from a hierarchical view of intelligence often referred to as the CattellHorn-Carroll or "three-stratum model" (McGrew, 2009). In this model, general intelligence, or $g$, resides at the top of the hierarchy, and it is divided at the second stratum into a series of eight to fifteen broad intelligences (Flanagan, McGrew, \& Ortiz, 2000; McGrew, 2009). The model is based on factor-analytic explorations of how mental abilities correlate with one another. Such analyses suggest that human thinking can be fruitfully divided into areas such as fluid reasoning, comprehension-knowledge (similar to verbal intelligence), visual-spatial processing, working memory, long-term storage and retrieval, and speed of retrieval. The three-stratum model also includes at its lowest level more specific mental abilities. For example, the broad intelligence, 
"comprehension-knowledge" includes the specific ability to understand vocabulary and general knowledge about the world.

Broad intelligences fall into subclasses (McGrew, 2009; Schneider \& Newman, 2015). One class of broad intelligences reflects basic functional capacities of the brain such as mental processing speed and the scope of working memory. A second class of broad intelligences such as auditory intelligence and tactile/physical intelligence is distinguishable by the sensory system with which it is most closely associated. Still others may reflect subject matter knowledge such as verbal intelligence. Mental abilities in late adolescence and adulthood may be shaped and strengthened into "aptitude complexes" by educational pursuits and interests to form domainspecific knowledge such as in mathematics, sciences, or government and history (Ackerman \& Heggestad, 1997; Rolfhus \& Ackerman, 1999).

Emotional intelligence fits such descriptions of a broad intelligence. MacCann, Joseph, Newman and Roberts (2014) collected data on 702 students who took a wide range of intelligence tests, including one of emotional intelligence, over an eight-hour testing period. Using confirmatory factor analysis, MacCann et al. (2014) found that emotional intelligence, indicated by three of the four branches of the Mayer, Salovey, Caruso Emotional Intelligence Test (MSCEIT, Mayer, Salovey, \& Caruso, 2002), fit well among other known broad intelligences within the second-stratum of the Cattell-Horn-Carroll model. In a reanalysis of the same data, Legree et al. (2014) were also able to fit emotional intelligence into the Cattell-HornCarroll framework; they included all four branches of the MSCEIT as indicators of emotional intelligence by correcting for the different response scales used across the test's subtasks (Legree et al., 2014).

\section{Principle 7: Emotional Intelligence is a Member of the Class of Broad Intelligences Focused on Hot Information Processing}

We believe that the broad intelligences - especially those defined by their subject matter - can be divided into hot and cool sets. Cool intelligences are those that deal with relatively impersonal knowledge such as verbal-propositional intelligence, math abilities, and visual-spatial intelligence. We view hot intelligences as involving reasoning with information of significance to an individual-matters that may chill our hearts or make our blood boil. People use these hot intelligences to manage what matters most to them: their senses of social acceptance, identity coherence, and emotional well being. Repeated failures to reason well in these areas lead to psychic pain which - at intense levels - is co-processed in the same brain centers that process physical pain (Eisenberger, 2015). By thinking clearly about feelings, personality, and social groups, however, people can better evaluate, cope with, and predict the consequences of their own actions, and the behavior of the individuals around them.

Emotional intelligence falls within this category because emotions are organized responses involving physical changes, felt experiences, cognitions, and action plans - all with strong evaluative components (Izard, 2010). Social intelligence is another member of the category (Conzelmann, Weis, \& Süß, 2013; Hoepfner \& O'Sullivan, 1968; Weis \& Süß, 2007; Wong, Day, Maxwell, \& Meara, 1995). Social intelligence is "hot" because social acceptance is fundamentally important to us; among social animals, group exclusion is a source of primal pain (Baumeister \& Leary, 1995). Finally, personal intelligence — an intelligence about personalityis a newly proposed member of this group (Mayer, 2008; Mayer, Panter, \& Caruso, 2012; Mayer, 2014). Personal intelligence is a hot intelligence because our sense of self is a primary source of inner pleasure and pain-ranging from self-satisfaction and pride on the positive side to selfloathing and suicidal thoughts and action on the negative side (Freud, 1962; Greenwald, 1980). 


\section{Summary and Applications}

In this section, we described seven principles that guide our thinking about emotional intelligence. We employed some of these principles - notably that emotional intelligence is an ability and a hot intelligence - from the outset of our work. We also introduced some new principles, such as those concerning broad intelligences. In the next section, we review the fourbranch model of emotional intelligence and present an updated view of our model and of our present thinking, recognizing that these principles could lead to other models as well.

\section{The Four-Branch Model: Original and Revised}

In this section of the paper, we briefly revisit our 1997 four-branch model of emotional intelligence and then proceed to renew it - as well as to clarify its range of usefulness in the context of the field's current understanding of intelligences. More specifically, we (a) add more abilities to the model, (b) distinguish the four-branch model of problem-solving content from the structure of human abilities relevant to emotional intelligence, (c) relate emotional intelligence to closely-allied broad intelligences, (d) examine the key characteristics of the problem-solving involved, and (e) more clearly distinguish between areas of problem-solving and areas of human mental abilities.

\section{The Four-Branch Model of Emotional Intelligence}

Our four-branch ability model distinguished among four branches of problem-solving necessary to carry out emotional reasoning: The first was (a) perceiving emotions, which we regarded as computationally most basic. We then proceeded through the increasingly integrated and more cognitively complex areas of (b) facilitating thought by using emotions, (c) understanding emotions, and (d) managing emotions in oneself and others (Mayer \& Salovey, 1997). (We referred to these problem-solving areas as branches after the line drawing in our original diagram).

Each branch represents a group of skills that proceeds developmentally from basic tasks to more challenging ones. The perceiving emotions branch leads off with the "ability to identify emotions in one's physical states, feelings, and thoughts," and proceeds to such developmentally advanced tasks (as we saw them then) as the ability to discriminate between truthful and dishonest expressions of feeling. The parallel developmental progression in the Understanding branch begins with the ability to label emotions and progressed to more challenging tasks such as understanding "likely transitions among emotions," such as from anger to satisfaction.

\section{Update 1. The Model Includes More Problem-Solving Abilities than Before}

Table 1 recapitulates the four branches of the original model in its four rows, from perceiving emotions to managing emotions (see left column). To the right, we have included many of the original specific types of reasoning that illustrated each branch, sometimes rewriting them for clarity. Within a row, each set of abilities is arranged, very approximately, from the simplest to the most complex skills (from bottom to top). 
Table 1

The Four-Branch Model of Emotional Intelligence, with Added Areas of Reasoning ${ }^{\mathrm{a}}$

\begin{tabular}{|c|c|}
\hline $\begin{array}{l}\text { 4. Managing } \\
\text { Emotions }\end{array}$ & $\begin{array}{l}\text { - Effectively manage other's emotions to achieve a desired outcome } \\
\text { - Effectively manage one's own emotions to achieve a desired outcome } \\
\text { - Evaluate strategies to maintain, reduce or intensify an emotional response } \\
\text { - }{ }^{b} \\
\text { - } \text { Enonitor emotional reactions to determine their reasonableness } \\
\text { - Stay open to pleasant and unpleasant feelings, as needed, and to the } \\
\text { information they convey }\end{array}$ \\
\hline $\begin{array}{l}\text { 3. Understanding } \\
\text { Emotions }\end{array}$ & $\begin{array}{l}\text { - Recognize cultural differences in the evaluation of emotions } s^{\mathrm{c}} \\
\text { - Understand how a person might feel in the future or under certain } \\
\text { conditions (affective forecasting) }{ }^{\mathrm{c}} \\
\text { - Recognize likely transitions among emotions such as from anger to } \\
\text { - } \text { satisfaction } \\
\text { - Understand complex and mixed emotions } \\
\text { - } \text { Aifferentiate between moods and emotions }{ }^{\mathrm{c}} \\
\text { - } \text { Appraise the situations that are likely to elicit emotions }{ }^{\mathrm{c}} \\
\text { - } \text { Label emotions and recognize relations among them }\end{array}$ \\
\hline $\begin{array}{l}\text { 2. Facilitating } \\
\text { Thought Using } \\
\text { Emotion }^{\mathrm{d}}\end{array}$ & $\begin{array}{l}\text { - Select problems based on how one's ongoing emotional state might } \\
\text { facilitate cognition } \\
\text { - Leverage mood swings to generate different cognitive perspectives } \\
\text { - } \text { Prioritize thinking by directing attention according to present feeling } \\
\text { - Generate emotions as a means to relate to experiences of another person } \\
\text { - } \\
\text { - Generate emotions as an aid to judgment and memory }\end{array}$ \\
\hline $\begin{array}{l}\text { 1. Perceiving } \\
\text { Emotion }\end{array}$ & 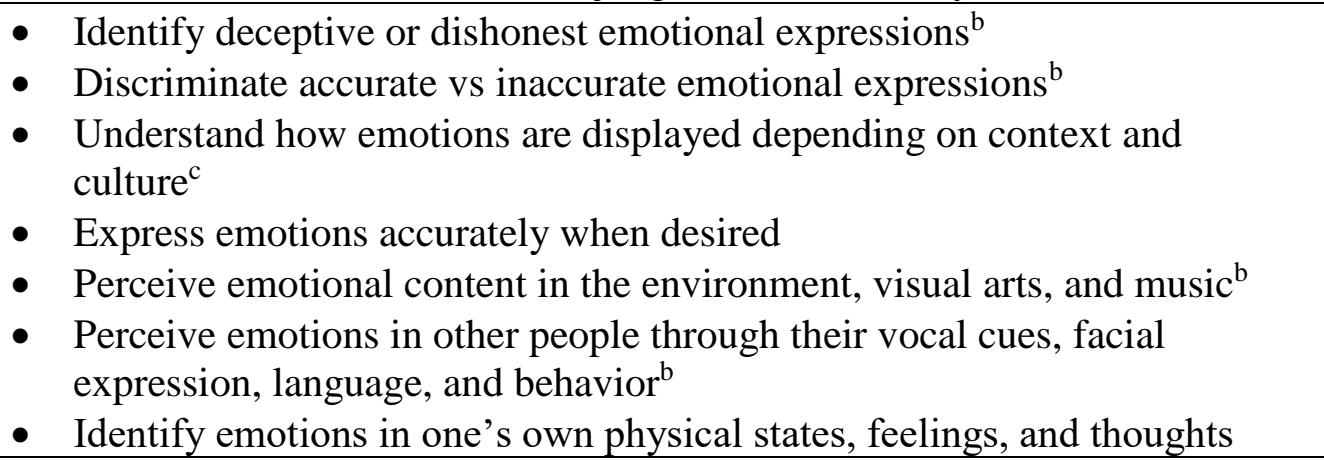 \\
\hline
\end{tabular}

${ }^{\mathrm{a}}$ The bullet-points are based on Mayer \& Salovey (1997) except as indicated in footnotes b and c. The bulleted items are ordered bottom-to-top within a row (very roughly) from simplest to most complex problem solving involved. Please note that the Four-Branch Model depicts the problem-solving areas of emotional intelligence and is not intended to correspond to the factor structure of the area.

${ }^{\mathrm{b}}$ An ability from the original model was divided into two or more separate abilities.

${ }^{\mathrm{c}}$ A new ability was added.

${ }^{\mathrm{d}}$ Note that the Branch 2 abilities can be further divided into the areas of generating emotions to facilitate thought (bottom two bulleted items) and tailoring thinking to emotion (the top three bulleted items). 
Based on research since 1997, we have added several areas of problem solving to this revised model that initially we overlooked. For example, the "Understanding Emotion" area originally included the abilities to label emotions, to know their causes and consequences, and to understand complex emotions. To those original areas of understanding, we have added emotional appraisal and emotional forecasting - topics that have experienced increased research attention and that have been directly related to emotionally intelligent reasoning (see also Barrett, Mesquita, \& Gendron, 2011; Dunn, Brackett, Ashton-James, Schneiderman, \& Salovey, 2007; MacCann \& Roberts, 2008), as well as a sensitivity to cultural contexts (Matsumoto \& Hwang, 2012). As others have pointed out, reasoning in an individual area is not necessarily discrete; rather, problem-solving activities can spill or cascade into one another. For example, emotion perception is often helpful to accurate emotion understanding (see Joseph \& Newman, 2010).

\section{Update 2: The Mental Abilities Involved in Emotional Intelligent Reasoning Remain To- Be-Determined}

When we first proposed the four-branch model, we believed it could reasonably correspond to four mental ability factors in the area (Mayer \&Salovey, 1997). That said, the content domains are independent of the mental abilities within the domain (by Principles Four and Five). In fact, the four-branch model is not well reflected in the factor structure of our ability-based measures (Legree et al., 2014; Maul, 2011; Palmer, Gignac, Manocha, \& Stough, 2005; Rossen, Kranzler, \& Algina, 2008).

From an empirical standpoint, tasks on the Mayer-Salovey-Caruso-Emotional Intelligence Test (MSCEIT) have been represented by between one and three factors (Legree et al., 2014; MacCann et al., 2014). Those theorists who favor a three-factor model have argued that Branch 2, Using Emotions to Facilitate Thought, be dropped because psychometric models of the test that try to model those tasks do not fit well (Joseph \& Newman, 2010).

We agree that the empirical evidence is reasonably clear that no mental ability factor related to Using Emotions to Facilitate Thought (Branch 2) emerges from the problem solving areas of the MSCEIT. This may be a failure of the test construction, or because people solve Branch 2 problems using their ability at emotional understanding (or another ability) rather than any reasoning distinctly related to Using Emotions. Whatever the reason, no strong evidence exists for a Using Emotions factor.

Given the empirical findings, should Using Emotions (Branch 2) be dropped as a subject area? We believe it makes sense to include Using Emotions in specifying the content of emotional intelligence because Using Emotions may well increase one's intelligence - and that is relevant to emotional intelligence. Knowing that it often makes more sense to do detail-oriented work when one is sad rather than happy - and that creativity burgeons with happiness - seems to us integral to the construct (Isen, Daubman, \& Nowicki, 1987), and additional findings point to the idea that people use inner emotional states to solve problems (Cohen \& Andrade, 2004; Leung et al., 2014)

But if Branch 2 helps specify the problem-solving content of the area, it does not map on to any empirical findings of relevant latent abilities (Haig, 2005). For that reason, the Using Emotions scale of the MSCEIT, for example, represents emotional intelligence in general, but lacks evidence for its specific structural validity. The four-branch model of emotional intelligence is a useful demarcation of the problem-solving content of the area. In this instance, however, the mental abilities involved in solving problems in emotional intelligence do not appear to coincide with the four areas. 


\section{Update 3. Emotional Intelligence Is A Broad Intelligence and Invites Comparisons and Contrasts with Related Hot Intelligences Such as Social and Personal Intelligences}

In our early works we sometimes wrote that emotional intelligence was similar to social intelligence (Mayer \& Salovey, 1993; Salovey \& Mayer, 1990) and at other times we described emotional intelligence as sui generis - it did not appear to be like any other intelligence - surely nothing in the Cattell-Horn-Carroll model as originally formulated. Neither of these positions appear helpful today.

Today, we believe there exists a group of hot intelligences of which emotional intelligence is a member. Two other candidates for this group are social intelligence and personal intelligence (see Principle 7). Some of these intelligences are better understood than others.

Social intelligence has been the most challenging to measure (Conzelmann et al., 2013; Romney \& Pyryt, 1999; Wong et al., 1995). Work conducted early in the $20^{\text {th }}$ century indicated that social intelligence correlated so highly with general intelligence as to be indistinguishable from it (Wyer \& Srull, 1989). Recent research bears this out: Conzelmann, Weis and Süß (2007) found that both social memory and social perception appeared to blend into general intelligence, consistent with earlier studies. They also found, however, more promising evidence for an independent social understanding task.

Another currently researched member of this group is personal intelligence: the capacity to reason about personalities - both one's own and the personalities of others. There is now preliminary evidence that personal intelligence can be measured, exists, and predicts consequential outcomes (Mayer \& Skimmyhorn, 2015b; Mayer et al., 2012).

The existence of other hot broad intelligences that form a group with emotional intelligence arguably does more to jeopardize the conceptual integrity of emotional intelligence than any other development in the past 25 years. After all, if emotional intelligence were just a part of the arguably broader personal intelligence, and could not be distinguished from it empirically, then emotional intelligence might need to be subsumed into that broader intelligence. It is for that reason that we focus next on a comparative examination of these hot intelligences.

Comparative definitions. To fully understand emotional intelligence, it helps to think about its relationship to personal and social intelligences. Emotional, personal, and social intelligences share in common their concern for the human world of inner experience and outer relationships. That is, they concern the understanding of people from their biosocial needs to their interactions in social groups. To compare these intelligences, we provide working definitions of each one in the first row of Table 2. Emotional intelligence is defined as "The ability to reason validly with emotions and with emotion-related information and to use emotions to enhance thought" (Table 2, column 2). Similar definitions are offered for personal and social intelligences. Definitions can provide a helpful start to specifying the members of the class of hot intelligences.

Problem-Solving Areas Involved. The three intelligences can be specified in a second way by describing each one's area of problem-solving. Emotional intelligence draws on problems described in the four branch model. Personal intelligence has similarly been divided into four problem solving areas (Table 2, column 3) that include (a) identifying personalityrelated information, (b) forming models of personality, (c) guiding personal choices and (d) systematizing life goals and plans (Mayer, 2009). Once again, we remind readers that (as we now view it) problem-solving areas do not necessarily predict the structure of mental abilities used to find solutions to those problems. In fact, the evidence indicates that simpler models may describe 
mental abilities in both emotional and personal intelligences (Legree et al., 2014; MacCann et al., 2014; Mayer, Panter, \& Caruso, 2014).

Table 2

A Comparison of Emotional, Personal and Social Intelligences

\begin{tabular}{|c|c|c|c|}
\hline \multirow{2}{*}{$\begin{array}{l}\text { Characterization } \\
\text { of intelligence }\end{array}$} & \multicolumn{3}{|c|}{ Type of Hot Intelligence } \\
\hline & Emotional & Personal & Social \\
\hline Brief Definition & $\begin{array}{l}\text { The ability to reason } \\
\text { validly with emotions and } \\
\text { with emotion-related } \\
\text { information, and to use } \\
\text { emotions to enhance } \\
\text { thought. }\end{array}$ & $\begin{array}{l}\text { The ability to reason about } \\
\text { personality-both our own and } \\
\text { the personalities of others- } \\
\text { including about motives and } \\
\text { emotions, thoughts and } \\
\text { knowledge, plans and styles of } \\
\text { action, and awareness and self- } \\
\text { control. }\end{array}$ & $\begin{array}{l}\text { The ability to understand social } \\
\text { rules, customs, and } \\
\text { expectations, social situations } \\
\text { and the social environment, } \\
\text { and to recognize the exercise of } \\
\text { influence and power in social } \\
\text { hierarchies. It also includes an } \\
\text { understanding of intra- and } \\
\text { inter-group relations. }\end{array}$ \\
\hline $\begin{array}{l}\text { Problem- } \\
\text { Solving } \\
\text { Areas }\end{array}$ & $\begin{array}{l}\text { Identify emotional } \\
\text { content in faces, } \\
\text { voices, and designs } \\
\text { and ability to } \\
\text { accurately express } \\
\text { emotions } \\
\text { Facilitate thinking by } \\
\text { drawing on emotions } \\
\text { as motivational and } \\
\text { substantive inputs } \\
\text { Understand the } \\
\text { meaning of emotions } \\
\text { and their implications } \\
\text { for behavior } \\
\text { Manage emotions in } \\
\text { oneself and others }\end{array}$ & $\begin{array}{l}\text { - Identify information about } \\
\text { personality, including } \\
\text { introspection into one's } \\
\text { feelings and reading } \\
\text { personality from faces } \\
\text { - Form models of personality } \\
\text { including labeling traits in } \\
\text { ourselves and others and } \\
\text { recognizing defensive } \\
\text { thinking } \\
\text { Guide personal choices } \\
\text { with inner awareness, } \\
\text { including discovering } \\
\text { personal interests and } \\
\text { making personality-relevant } \\
\text { decisions } \\
\text { Systematize plans and } \\
\text { goals, including finding a } \\
\text { satisfying life direction and } \\
\text { meaning }\end{array}$ & $\begin{array}{l}\text { - Identify group } \\
\text { memberships: recognize } \\
\text { dyadic relationships; } \\
\text { understand group relations } \\
\text { such as age, gender, ethnic, } \\
\text { socio-economic and other } \\
\text { groups } \\
\text { Identify social dominance } \\
\text { and other power dynamics } \\
\text { among groups } \\
\text { Understand contributors to } \\
\text { group morale, cohesion, } \\
\text { and dissolution } \\
\text { Understand how groups use } \\
\text { power among one another } \\
\text { Recognize and understand } \\
\text { the exercise of leadership } \\
\text { and group power }\end{array}$ \\
\hline $\begin{array}{l}\text { Aims of } \\
\text { Reasoning }\end{array}$ & $\begin{array}{l}\text { To achieve desired } \\
\text { emotional states and } \\
\text { experiences in oneself } \\
\text { and others }\end{array}$ & $\begin{array}{l}\text { To attain goals of self- } \\
\text { development, effective } \\
\text { personal action, and desired } \\
\text { interactions with others }\end{array}$ & $\begin{array}{l}\text { To achieve membership } \\
\text { status in preferred groups, } \\
\text { and to influence the } \\
\text { reputation of the group in a } \\
\text { desired way }\end{array}$ \\
\hline
\end{tabular}

The problem solving areas for social intelligence are less well demarcated. From our standpoint, Conzelmann et al. (2013) examined something closer to personal intelligence than social intelligence in their operationalization of social understanding: They asked test-takers to 
guess the background information of a target person and to judge the person's mental states (including emotions and thoughts). A definition of social intelligence that better distinguishes it from emotional and personal intelligences would focus on reasoning about groups and relationships between individuals and groups. The relevant areas of reasoning, as we see them, are shown in Table 2, column 3.

\section{Update 4: Positioning Emotional Intelligence Among Other Hot Intelligences}

Emotional intelligence, personal intelligence and social intelligence can be "positioned" amidst one another in different ways. We suspect that the three intelligences themselvesemotional, personal and social - may each be of comparable complexity in that they all involve human cognitive reasoning of an equally sophisticated nature.

At the same time, the problem-solving they address - about emotions, personality characteristics, and social processes - concern systems at three different levels of complexity: emotions are relatively small psychological subsystems; personality exists at the level of the whole individual; social organizations involve groups of people. More formally, the phenomena being reasoned about occupy different levels along the biopsychosocial continuum, with emotions lowest and social systems highest (Engel, 1977; Sheldon, Cheng, \& Hilpert, 2011).

One matter that remains indeterminate is, therefore, whether all three intelligences can be considered broad intelligences, or whether, alternatively, emotional intelligence (because it concerns the smallest system) is a specific ability within personal (or social) intelligence. For now, it seems reasonable to keep them separate until such a time as mathematical models indicate that models that nest them yield a superior fit.

Finally, all three intelligences concern understanding the human world, and yet, because their topic areas are sufficiently diverse, the capacity to reason in each area may be somewhat independent of one another. Some people may possess considerable social intelligence without having a good deal of emotional intelligence; some people may possess personal intelligence without social intelligence. That said, most people will employ the intelligences in an intertwined fashion. It is easier to understand personality if one has a reasonable feel for a person's emotions; easier to understand people if one understands the social systems they operate within, and so forth. These relationships explain why the intelligences - even though they can be defined in discrete terms to a considerable degree - are likely to correlate at substantial levels.

\section{Update 5: Specifying the Problem Analyses of the Broad Intelligences}

Whatever the structure of human intelligences turns out to be, demarcating the reasoning involved is important to educating people so as to improve their problem solving in the areaand also may contribute to the implementation of formal problem solving in the area using artificial intelligence. Our model can be expanded to describe the units, operators, and solutions of each intelligence that people manipulate to analyze a problem. Our concept of problem analysis borrows heavily from Newell and Simon's (1972) concept of the "problem space". Their aim was to show "in detail how the processes that occur in human problem solving can be compounded out of elementary information processes..." (Newell, Shaw, \& Simon, 1958, p. 152).

People create a mental problem space when they recognize and encode a problem they hope to solve. Within the problem space, they specify the criteria for a correct solution, as well as rules to solve it by. Individuals may also set up intermediate stages of problem solving: parts of the problem that can be solved individually and are likely to contribute to an ultimate solution (Newell \& Simon, 1972, p. 59). In Newell et al.'s formulation, people solve problems by identifying: (a) a finite set of information (items, relationships among them, and knowledge 
about them), (b) a small and finite set of operators, and (c) a small number of alternative possible solutions (Newell \& Simon, 1972, pp. 810-811). Related models of intelligence that anticipate such divisions - or are influenced by them-include Guilford's Structure of Intellect Model and the Berlin Model of Intelligence both of which pair operators with contents (Beauducel \& Kersting, 2002; Guilford, 1966; 1988).

These approaches from human and artificial intelligence share the idea that test takers have a certain amount of information at their disposal, can operate on that information in certain valid ways and come up with a set of possible answers. Consequently, specifying the units, operators, and solutions to a specific problem further helps to describe the problem-solving intrinsic to a given task.

A proposed problem space for emotional and personal intelligences is provided in Table 3. For example, a person might apply emotional intelligence to the question of whether a friend is sad. To answer the question, the person will draw on units that include facial expressions, tone of voice, mood-congruent judgment and situational appraisals. The problem-solver then operates on those units given a specific problem. For example, by perceiving her friend's flaccid facial expression, understanding a setback he suffered, and hearing his negative attitude, she is likely to conclude her friend is sad. A parallel breakdown is specified in Table 3 for an example pertinent to personal intelligence.

Such analyses point out how the hot intelligences emphasize somewhat different units of analysis. For emotions, the units involve facial expressions, emotions, and mood-congruent judgment; for personal intelligence, traits, behaviors, and relationship status are important. Each of the hot intelligences is likely to emphasize different classes of units - although there is some overlap as well: Both emotional and personal intelligence make use of situation understanding.

Educators, intelligence researchers and computer scientists can make use of these analyses. For example, educators can develop new curricula that focus on the units of problem solving and that explain the varieties of reasoning involved; educators who understand the units and operators involved can better teach problem solving in the area.

\section{Discussion}

Twenty-five years after its introduction, a good deal of evidence has accumulated that emotional intelligence exists as a mental ability among the class of hot, broad intelligences. Ability measures of emotional intelligence are still evolving, and the factor structure of the area remains uncertain - although support exists for both one- and three-factor models (Legree et al., 2014; MacCann et al., 2014). Emotional intelligence could turn out to be a part of a larger personal or social intelligence. We further know that emotional intelligence predicts important outcomes.

If emotional intelligence is a discrete intelligence, we need to make the case that there has evolved a separate reasoning capacity to understand emotions. In fact, there is some evidence to support this idea. For example Heberlein and colleagues showed that the brain areas responsible for perceiving emotional expressions - happiness, fear and anger - are to a degree distinct from the brain areas for perceiving expressions of personality - shyness, warmth and unfriendliness (Heberlein, Adolphs, Tranel, \& Damasio, 2004; Heberlein \& Saxe, 2005). 
Table 3

Examples of Problem Analysis in the Realms of Emotional and Personal Intelligences

\begin{tabular}{|c|c|c|c|c|}
\hline & \multicolumn{2}{|c|}{ Emotional Intelligence } & \multicolumn{2}{|c|}{ Personal Intelligence } \\
\hline & $\begin{array}{l}\text { Key Members of the } \\
\text { Sets }\end{array}$ & $\begin{array}{c}\text { Example of a } \\
\text { Specific Problem }\end{array}$ & $\begin{array}{l}\text { Key Members of the } \\
\text { Sets }\end{array}$ & $\begin{array}{c}\text { Example of a } \\
\text { Specific Problem }\end{array}$ \\
\hline $\begin{array}{l}\text { To-be-solved } \\
\text { problem }\end{array}$ & $\begin{array}{l}\text { Perceive a person's } \\
\text { emotion }\end{array}$ & Does a friend feel sad? & $\begin{array}{l}\text { Understand a person's } \\
\text { likely behavior }\end{array}$ & $\begin{array}{l}\text { Is a colleague at work } \\
\text { vengeful toward a } \\
\text { coworker? }\end{array}$ \\
\hline \multirow[t]{4}{*}{ Units involved } & $\begin{array}{l}\text { Emotional facial } \\
\text { expressions }\end{array}$ & $\begin{array}{l}\text { The friend's mouth is } \\
\text { downturned }\end{array}$ & $\begin{array}{l}\text { Relationship status } \\
\text { Situations }\end{array}$ & $\begin{array}{l}\text { The coworker insulted the } \\
\text { colleague in public }\end{array}$ \\
\hline & Postural changes & $\begin{array}{l}\text { The friend's movements } \\
\text { are slowed down }\end{array}$ & Behaviors & $\begin{array}{l}\text { The colleague fails to pass } \\
\text { on potentially helpful } \\
\text { information to the } \\
\text { coworker }\end{array}$ \\
\hline & $\begin{array}{l}\text { Mood-congruent } \\
\text { judgment }\end{array}$ & $\begin{array}{l}\text { The friend is critical and } \\
\text { pessimist about the } \\
\text { future }\end{array}$ & Traits & $\begin{array}{l}\text { The colleague is generally } \\
\text { helpful to other coworkers }\end{array}$ \\
\hline & Situational appraisals & $\begin{array}{l}\text { The friend just lost a } \\
\text { relationship with a } \\
\text { loved one }\end{array}$ & Principles of success & $\begin{array}{l}\text { In an office, knowledge can } \\
\text { be empowering }\end{array}$ \\
\hline \multirow[t]{3}{*}{$\begin{array}{l}\text { Operators } \\
\text { employed }\end{array}$} & $\begin{array}{l}\text { Translating facial } \\
\text { expressions into } \\
\text { emotions }\end{array}$ & $\begin{array}{l}\text { The friend has a sad } \\
\text { facial expression }\end{array}$ & $\begin{array}{l}\text { Translating a trait into a } \\
\text { likely behavior }\end{array}$ & $\begin{array}{l}\text { The colleague would } \\
\text { normally have remembered } \\
\text { to share the information }\end{array}$ \\
\hline & $\begin{array}{l}\text { Recognizing a loss } \\
\text { can lead to sadness }\end{array}$ & $\begin{array}{l}\text { The friend's lost love is } \\
\text { likely to make him feel } \\
\text { sad }\end{array}$ & $\begin{array}{l}\text { Identifying possible } \\
\text { alternative traits and } \\
\text { goals }\end{array}$ & $\begin{array}{l}\text { The colleague could be } \\
\text { careless, vengeful or } \\
\text { forgetful }\end{array}$ \\
\hline & $\begin{array}{l}\text { Knowing how an } \\
\text { emotion will change } \\
\text { with time }\end{array}$ & $\begin{array}{l}\text { He will likely cheer up } \\
\text { with time }\end{array}$ & $\begin{array}{l}\text { Evaluating two goals } \\
\text { for the conflicts } \\
\text { between them }\end{array}$ & $\begin{array}{l}\text { The colleague often likes to } \\
\text { be helpful but the pattern of } \\
\text { events and actions fits a } \\
\text { goal of vengeance }\end{array}$ \\
\hline $\begin{array}{l}\text { Possible } \\
\text { solutions }\end{array}$ & $\begin{array}{l}\text { Converging } \\
\text { information leads to a } \\
\text { "best guess" } \\
\text { solution/prediction }\end{array}$ & $\begin{array}{l}\text { Yes, the situation and } \\
\text { the facial expression } \\
\text { converge on the idea the } \\
\text { friend is sad }\end{array}$ & $\begin{array}{l}\text { Converging information } \\
\text { leads to a "best guess" } \\
\text { solution/prediction }\end{array}$ & $\begin{array}{l}\text { Yes, the colleague acted } \\
\text { vengefully against the } \\
\text { coworker because of the } \\
\text { insult }\end{array}$ \\
\hline
\end{tabular}

Correlations among broad intelligence range greatly. In one study of ours, spatial and personal intelligences, which are conceptually very distinct, correlated $r=.23$ (Mayer \& Skimmyhorn, 2015a); in another, personal intelligence and aspects of emotional intelligence were related $r=.69$ suggesting they are closely related intelligences (Mayer et al., 2012).

Thus, there is the possibility that emotional intelligence seamlessly operates as part a broader personal or social intelligence, or a combined socio-emotional-personal intelligence. In this instance, there would be nothing special or unique about an individual's ability to reason about emotions; rather, it would be part of a broader reasoning about human nature. In that eventuality, the construction of tests of emotional intelligence would be nothing more than the construction of a subscale of a broader test. 
Twenty-five years after the fact, our view is fairly sanguine: We believe that it is likely emotional intelligence will be partly distinct from both personal and social intelligences. Even if it is not, there has been much to gain and little to lose from working out the reasoning employed to understand emotions. Emotional intelligence has helped to codify at least some of the abundance of emotion research from the 1970s forward, indicating that there are indeed rules for reasoning about emotions and that knowing such rules is adaptive.

By using the principles developed here to understand how people solve problems in the area of emotions, we can improve education in the subject matter. Once the problems in an area such as understanding emotions are well-described, educators can teach people how to think better about them (Durlak, Weissberg, Dymnicki, Taylor, \& Schellinger, 2011; Rivers, Brackett, Reyes, Elbertson, \& Salovey, 2013). Such understanding also enables computer scientists to create expert systems that emulate human reasoning - matters of importance with the growing relevance of expert computer systems and robots in our lives. For example, Cambria and colleagues describe the common sense computer movement which seeks to construct expert systems that contain tacit knowledge about the world of all sorts (Cambria, Hussain, Havasi, \& Eckl, 2009, p. 253); they hope such machines "extract users' emotions and attitudes and use this information to be able to better interact with them" (Cambria et al., 2009, p. 258).

\section{Concluding Comments}

People engage with different subject matter when they use hot intelligences. The revised four-branch model developed here provides an overview of the problem content involved in emotional intelligence; related models covered here outline content for personal and social intelligences. These content specifications are relevant to evaluating test coverage in the area, but are less relevant as suggestions of the underlying mental abilities that people employ to solve problems in the area.

The principles stated in this article suggest that it will sometimes make sense to consider emotional, personal and social intelligences as a set and to be sensitive to their distinctions and overlap. Moreover, just as our understanding of emotional intelligence has depended upon the development of ability measures, however imperfect, so must personal, social and related intelligences develop their own measures - as is happening now (Allen, Weissman, Hellwig, MacCann, \& Roberts, 2014; Conzelmann et al., 2013; Mayer et al., 2012; Mayer et al., 2014). This will take some time and our measures and our data are always fallible. In 1990 there were virtually no data relevant to these topics, whereas now there is some. As Funder $(2013$, p. 56) has reminded us, data are always fallible. The only thing worse than the fallible data we have on these topics today is the nearly total absence of relevant data we had in 1990.

\section{References}

Ackerman, P. L., \& Heggestad, E. D. (1997). Intelligence, personality, and interests: Evidence for overlapping traits. Psychological Bulletin, 121(2), 219-245. doi:10.1037/00332909.121.2.219

Ackerman, P. L., \& Kanfer, R. (2004). Cognitive, affective, and conative aspects of adult intellect within a typical and maximal performance framework. In D. Y. Dai, R. J. Sternberg, D. Y. (. Dai \& R. J. (. Sternberg (Eds.), (pp. 119-141). Mahwah, NJ, US: Lawrence Erlbaum Associates Publishers.

Allen, V. D., Weissman, A., Hellwig, S., MacCann, C., \& Roberts, R. D. (2014). Development of the short form of the situational test of emotional understanding-brief (STEU-B) using 
item response theory. Personality and Individual Differences, 65, 3-7.

doi:10.1016/j.paid.2014.01.051

Ayduk, O., \& Mischel, W. (2002). When smart people behave stupidly: Reconciling inconsistencies in social-emotional intelligence. In R. J. Sternberg, \& R. J. (. Sternberg (Eds.), (pp. 86-105). New Haven, CT, US: Yale University Press.

Barrett, L. F., Mesquita, B., \& Gendron, M. (2011). Context in emotion perception. Current Directions in Psychological Science, 20(5), 286-290. doi:10.1177/0963721411422522

Baumeister, R. F., \& Leary, M. R. (1995). The need to belong: Desire for interpersonal attachments as a fundamental human motivation. Psychological Bulletin, 117(3), 497-529. doi:10.1037/0033-2909.117.3.497

Beauducel, A., \& Kersting, M. (2002). Fluid and crystallized intelligence and the berlin model of intelligence structure (BIS). European Journal of Psychological Assessment, 18(2), 97-112. doi:10.1027//1015-5759.18.2.97

Brackett, M. A., Rivers, S. E., Shiffman, S., Lerner, N., \& Salovey, P. (2006). Relating emotional abilities to social functioning: A comparison of self-report and performance measures of emotional intelligence. Journal of Personality and Social Psychology, 91(4), 780-795. doi:10.1037/0022-3514.91.4.780

Cambria, E., Hussain, A., Havasi, C., \& Eckl, C. (2009). Common sense computing: From the society of mind to digital intuition and beyond. In J. Fierrez, J. Ortega-Garcia, A. Esposito, A. Drygajlo \& M. Faundez-Zanuy (Eds.), Biometric ID management and multimodal communication (pp. 252-259). Berlin: Springer-Verlag.

Carroll, J. B. (1993). Human cognitive abilities: A survey of factor-analytic studies. New York, NY US: Cambridge University Press.

Cohen, J. B., \& Andrade, E. B. (2004). Affective intuition and task-contingent affect regulation. Journal of Consumer Research, 31(2), 358-367. doi:10.1086/422114

Conzelmann, K., Weis, S., \& Süß, H. (2013). New findings about social intelligence: Development and application of the magdeburg test of social intelligence (MTSI). Journal of Individual Differences, 34(3), 119-137. doi:10.1027/1614-0001/a000106

Detterman, D. K. (1982). Does 'g' exist? Intelligence, 6(2), 99-108. doi:10.1016/01602896(82)90008-3

DeYoung, C. G. (2011). Intelligence and personality. In R. J. Sternberg \& S. B. Kaufman (Eds.), (pp. 711-737). New York, NY, US: Cambridge University Press. doi:10.1017/CBO9780511977244.036

Duckworth, A. L., Quinn, P. D., \& Tsukayama, E. (2012). What no child left behind leaves behind: The roles of IQ and self-control in predicting standardized achievement test scores and report card grades. Journal of Educational Psychology, 104(2), 439-451. doi: $10.1037 / \mathrm{a} 0026280$

Dunn, E. W., Brackett, M. A., Ashton-James, C., Schneiderman, E., \& Salovey, P. (2007). On emotionally intelligent time travel: Individual differences in affective forecasting ability. Personality and Social Psychology Bulletin, 33(1), 85-93. doi:10.1177/0146167206294201

Durlak, J. A., Weissberg, R. P., Dymnicki, A. B., Taylor, R. D., \& Schellinger, K. B. (2011). The impact of enhancing students' social and emotional learning: A meta-analysis of schoolbased universal interventions. Child Development, 82(1), 405-432. doi:10.1111/j.14678624.2010.01564.x 
Eisenberger, N. I. (2015). Social pain and the brain: Controversies, questions, and where to go from here. Annual Review of Psychology, 66, 601-629. doi:10.1146/annurev-psych-010213115146

Engel, G. L. (1977). The need for a new medical model: A challenge for biomedicine. Science, 196(4286), 129-136. doi:10.1126/science.847460

Flanagan, D. P., McGrew, K. S., \& Ortiz, S. O. (2000). The wechsler intelligence scales and gfgc theory: A contemporary approach to interpretation. Needham Heights, MA, US: Allyn $\&$ Bacon.

Freud, S. (1962). Civilization and its discontents. New York, NY: W.W. Norton.

Funder, D. C. (2013). The personality puzzle (6th ed.). New York: W. W. Norton.

Funder, D. C. (2001). Accuracy in personality judgment: Research and theory concerning an obvious question. In R. Hogan (Ed.), Personality psychology in the workplace. (pp. 121140). Washington, DC US: American Psychological Association. doi:10.1037/10434-005

Gottfredson, L. S. (1997). Mainstream science on intelligence: An editorial with 52 signatories, history and bibliography. Intelligence, 24(1), 13-23. doi:10.1016/S0160-2896(97)90011-8

Greenwald, A. G. (1980). The totalitarian ego: Fabrication and revision of personal history. American Psychologist, 35(7), 603-618. doi:10.1037/0003-066X.35.7.603

Greven, C. U., Harlaar, N., Kovas, Y., Chamorro-Premuzic, T., \& Plomin, R. (2009). More than just IQ: School achievement is predicted by self-perceived abilities-But for genetic rather than environmental reasons. Psychological Science, 20(6), 753-762. doi:10.1111/j.14679280.2009.02366.x

Guilford, J. P. (1966). Intelligence: 1965 model. American Psychologist, 21(1), 20-26. doi: $10.1037 / \mathrm{h} 0023296$

Guilford, J. P. (1988). Some changes in the structure-of-intellect model. Educational and Psychological Measurement, 48(1), 1-4. doi:10.1177/001316448804800102

Haig, B. D. (2005). An abductive theory of scientific method. Psychological Methods, 10(4), 371-388. doi:10.1037/1082-989X.10.4.371

Heberlein, A. S., Adolphs, R., Tranel, D., \& Damasio, H. (2004). Cortical regions for judgments of emotions and personality traits from point-light walkers. Journal of Cognitive Neuroscience, 16(7), 1143-1158. doi:10.1162/0898929041920423

Heberlein, A. S., \& Saxe, R. R. (2005). Dissociation between emotion and personality judgments: Convergent evidence from functional neuroimaging. NeuroImage, 28(4), 770 777. doi:10.1016/j.neuroimage.2005.06.064

Hoepfner, R., \& O'Sullivan, M. (1968). Social intelligence and iq. Educational and Psychological Measurement, 28(2), 339-344. doi:10.1177/001316446802800211

Isen, A. M., Daubman, K. A., \& Nowicki, G. P. (1987). Positive affect facilitates creative problem solving. Journal of Personality and Social Psychology, 52(6), 1122-1131. doi:10.1037/0022-3514.52.6.1122

Izard, C. E. (2010). The many meanings/aspects of emotion: Definitions, functions, activation, and regulation. Emotion Review, 2(4), 363-370. doi:10.1177/1754073910374661

Izard, C. E., Fine, S., Schultz, D., Mostow, A., Ackerman, B., \& Youngstrom, E. (2001). Emotion knowledge as a predictor of social behavior and academic competence in children at risk. Psychological Science, 12(1), 18-23. R

Joint Committee. (2014). Standards for educational and psychological testing. Washington, DC US: American Psychological Association. 
Joseph, D. L., \& Newman, D. A. (2010). Emotional intelligence: An integrative meta-analysis and cascading model. Journal of Applied Psychology, 95(1), 54-78. doi:10.1037/a0017286

Karim, J., \& Weisz, R. (2010). Cross-cultural research on the reliability and validity of the mayer-salovey-caruso emotional intelligence test (MSCEIT). Cross-Cultural Research: The Journal of Comparative Social Science, 44(4), 374-404. doi:10.1177/1069397110377603

Legree, P. J., Psotka, J., Robbins, J., Roberts, R. D., Putka, D. J., \& Mullins, H. M. (2014). Profile similarity metrics as an alternate framework to score rating-based tests: MSCEIT reanalyses. Intelligence, 47, 159-174. doi:10.1016/j.intell.2014.09.005

Legree, P. J., Psotka, J., Tremble, T., \& Bourne, D. R. (2005). Using consensus based measurement to assess emotional intelligence. In R. Schulze, R. D. Roberts, R. (. Schulze \& R. D. (. Roberts (Eds.), (pp. 155-179). Ashland, OH, US: Hogrefe \& Huber Publishers.

Leung, A. K., Liou, S., Qiu, L., Kwan, L. Y., Chiu, C., \& Yong, J. C. (2014). The role of instrumental emotion regulation in the emotions-creativity link: How worries render individuals with high neuroticism more creative. Emotion, 14(5), 846-856. doi:10.1037/a0036965

MacCann, C., Joseph, D. L., Newman, D. A., \& Roberts, R. D. (2014). Emotional intelligence is a second-stratum factor of intelligence: Evidence from hierarchical and bifactor models. US: American Psychological Association.

MacCann, C., \& Roberts, R. D. (2008). New paradigms for assessing emotional intelligence: Theory and data. Emotion, 8(4), 540-551. doi:10.1037/a0012746; 10.1037/a0012746.supp (Supplemental)

Matsumoto, D., \& Hwang, H. S. (2012). Culture and emotion: The integration of biological and cultural contributions. Journal of Cross-Cultural Psychology, 43(1), 91-118. doi:10.1177/0022022111420147

Maul, A. (2011). The factor structure and cross-test convergence of the Mayer-Salovey-Caruso model of emotional intelligence. Personality and Individual Differences, 50(4), 457-463. doi:10.1016/j.paid.2010.11.007

Mayer, J. D., \& Skimmyhorn, W. (2015a). Broad intelligences and the big five predict cadet performance at west point. Unpublished manuscript.

Mayer, J. D., \& Skimmyhorn, W. (2015b). Psychological predictors of cadet performance at west point (originally titled: "Learning about personal intelligence from the test of personal intelligence). Association for Research in Personality, June, 2015, St. Louis, MO.

Mayer, J. D. (2008). Personal intelligence. Imagination, Cognition and Personality, 27(3), 209232. doi:10.2190/IC.27.3.b

Mayer, J. D. (2009). Personal intelligence expressed: A theoretical analysis. Review of General Psychology, 13(1), 46-58. doi:10.1037/a0014229

Mayer, J. D. (2014). Personal intelligence: The power of personality and how it shapes our lives. New York: Scientific American / Farrar Strauss \& Giroux.

Mayer, J. D., Panter, A. T., \& Caruso, D. R. (2012). Does personal intelligence exist? evidence from a new ability-based measure. Journal of Personality Assessment, 94, 124-140. doi:10.1080/00223891.2011.646108

Mayer, J. D., Panter, A. T., \& Caruso, D. R. (2014). Test of personal intelligence (TOPI 1.4) manual. Durham, NH: University of New Hampshire.

Mayer, J. D., Roberts, R. D., \& Barsade, S. G. (2008). Human abilities: Emotional intelligence. Annual Review of Psychology, 59, 507-536. doi:10.1146/annurev.psych.59.103006.093646 
Mayer, J. D., Salovey, P., \& Caruso, D. R. (2002). Mayer-Salovey-Caruso Emotional Intelligence Test (MSCEIT) Users Manual. Toronto, Ontario: Multi-Health Systems.

Mayer, J. D., \& Salovey, P. (1993). The intelligence of emotional intelligence. Intelligence, 17(4), 433-442. doi:10.1016/0160-2896(93)90010-3

Mayer, J. D., \& Salovey, P. (1997). What is emotional intelligence? In D. J. Sluyter (Ed.), Emotional development and emotional intelligence: Educational implications. (pp. 3-34). New York, NY US: Basic Books.

Mayer, J. D., Salovey, P., \& Caruso, D. R. (2008). Emotional intelligence: New ability or eclectic traits? American Psychologist, 63(6), 503-517. doi:10.1037/0003-066X.63.6.503

Mayer, J. D., Salovey, P., Caruso, D. R., \& Sitarenios, G. (2003). Measuring emotional intelligence with the MSCEIT V2.0. Emotion, 3(1), 97-105. doi:10.1037/1528-3542.3.1.97

McGrew, K. S. (2009). CHC theory and the human cognitive abilities project: Standing on the shoulders of the giants of psychometric intelligence research. Intelligence, 37(1), 1-10. doi:10.1016/j.intell.2008.08.004

Mischel, W. (2009). From Personality and Assessment (1968) to personality science, 2009. Journal of Research in Personality, 43(2), 282-290. doi:10.1016/j.jrp.2008.12.037

Newell, A., Shaw, J. C., \& Simon, H. A. (1958). Elements of a theory of human problem solving. Psychological Review, 65(3), 151-166. doi:10.1037/h0048495

Newell, A., \& Simon, H. A. (1972). Human problem solving. Oxford, England: Prentice-Hall.

Palmer, B. R., Gignac, G., Manocha, R., \& Stough, C. (2005). A psychometric evaluation of the mayer-salovey-caruso emotional intelligence test version 2.0. Intelligence, 33(3), 285-305. doi:10.1016/j.intell.2004.11.003

Paulhus, D. L., Lysy, D. C., \& Yik, M. S. M. (1998). Self-report measures of intelligence: Are they useful as proxy IQ tests? Journal of Personality, 66(4), 525-554. doi:10.1111/14676494.00023

Rivers, S. E., Brackett, M. A., Reyes, M. R., Elbertson, N. A., \& Salovey, P. (2013). Improving the social and emotional climate of classrooms: A clustered randomized controlled trial testing the RULER approach. Prevention Science, 14(1), 77-87. doi:10.1007/s11121-0120305-2

Roberts, R. D., Schulze, R., O'Brien, K., MacCann, C., Reid, J., \& Maul, A. (2006). Exploring the validity of the mayer-salovey-caruso emotional intelligence test (MSCEIT) with established emotions measures. Emotion, 6(4), 663-669. doi:10.1037/1528-3542.6.4.663

Rolfhus, E. L., \& Ackerman, P. L. (1999). Assessing individual differences in knowledge: Knowledge, intelligence, and related traits. Journal of Educational Psychology, 91(3), 511526. doi:10.1037/0022-0663.91.3.511

Romney, D. M., \& Pyryt, M. C. (1999). Guilford's concept of social intelligence revisited. High Ability Studies, 10(2), 137-142. doi:10.1080/1359813990100202

Rossen, E., \& Kranzler, J. H. (2009). Incremental validity of the mayer-salovey-caruso emotional intelligence test version 2.0 (MSCEIT) after controlling for personality and intelligence. Journal of Research in Personality, 43, 60-65. doi:10.1016/j.jrp.2008.12.002

Rossen, E., Kranzler, J. H., \& Algina, J. (2008). Confirmatory factor analysis of the mayer-salovey--caruso emotional intelligence test V 2.0 (MSCEIT). Personality and Individual Differences, 44, 1258-1269. doi:10.1016/j.paid.2007.11.020

Salovey, P., \& Mayer, J. D. (1990). Emotional intelligence. Imagination, Cognition and Personality, 9(3), 185-211. 
Schneider, W. J., \& Newman, D. A. (2015). Intelligence is multidimensional: Theoretical review and implications of specific cognitive abilities. Human Resource Management Review, 25(1), 12-27.

Sheldon, K. M., Cheng, C., \& Hilpert, J. (2011). Understanding well-being and optimal functioning: Applying the multilevel personality in context (MPIC) model. Psychological Inquiry, 22, 1-16.

Sternberg, R. J. (2004). Why smart people can be so foolish. European Psychologist, 9(3), 145150. doi:10.1027/1016-9040.9.3.145

Trentacosta, C. J., Izard, C. E., Mostow, A. J., \& Fine, S. E. (2006). Children's emotional competence and attentional competence in early elementary school. School Psychology Quarterly, 21(2), 148-170. doi:10.1521/scpq.2006.21.2.148

Wai, J., Lubinski, D., \& Benbow, C. P. (2009). Spatial ability for STEM domains: Aligning over 50 years of cumulative psychological knowledge solidifies its importance. Journal of Educational Psychology, 101, 817-835.

Weis, S., \& Süß, H. (2007). Reviving the search for social intelligence - A multitraitmultimethod study of its structure and construct validity. Personality and Individual Differences, 42(1), 3-14. doi:10.1016/j.paid.2006.04.027

Wong, C. T., Day, J. D., Maxwell, S. E., \& Meara, N. M. (1995). A multitrait-multimethod study of academic and social intelligence in college students. Journal of Educational Psychology, 87(1), 117-133. doi:10.1037/0022-0663.87.1.117

Wyer, R. S.,Jr. \& Srull, T. K.. (1989). In Srull T. K. (Ed.), Social intelligence and cognitive assessments of personality. Hillsdale, NJ England: Lawrence Erlbaum Associates, Inc. 